\title{
Growth and Movements of Mummichogs (Fundulus heteroclitus) Along Armored and Vegetated Estuarine Shorelines
}

\author{
Kevin P. Crum ${ }^{1,2} \cdot$ Richard G. Balouskus ${ }^{1,3}$ • Timothy E. Targett ${ }^{1}$
}

Received: 3 September 2016 / Revised: 14 July 2017 / Accepted: 25 July 2017 / Published online: 31 August 2017

(C) The Author(s) 2017, corrected publication 2019

\begin{abstract}
Alteration of estuarine shorelines associated with increased urbanization can significantly impact biota and food webs. This study determined the impact of shoreline alteration on growth and movement of the estuarine fish Fundulus heteroclitus in a tributary of the Delaware Coastal Bays. Fundulus heteroclitus is abundant along the east coast of the USA, and is an important trophic link between marsh and subtidal estuary. The restricted home range of $F$. heteroclitus allowed discrete sampling, and fish growth comparisons, along 35-65-m long stretches of fringing Spartina alterniflora and Phragmites australis marsh, riprap, and bulkhead. Fundulus heteroclitus were tagged with decimal Coded Wire Tags. Of 725 tagged $F$. heteroclitus, 89 were recaptured 30 63 days later. Mean growth rate $\left(0.06-0.15 \mathrm{~mm}^{-1 a y}{ }^{-1}\right.$ across all shoreline types) was greatest at riprap, lowest at Spartina and Phragmites, and intermediate at bulkhead, where growth was not significantly different from any other shoreline. This suggests that discernible environments exist along different shoreline types, even at the scale of tens of meters. No difference in movement distance was detected at different shoreline types; most individuals displayed a high degree of site fidelity. Forty-seven percent were recaptured within $5 \mathrm{~m}$ of their
\end{abstract}

Communicated by Matthew D. Taylor

Kevin P. Crum

crumkev@gmail.com

1 School of Marine Science and Policy, University of Delaware, Lewes, DE 19958, USA

2 Present address: PreciseTarget, 7201 Wisconsin Avenue, Suite 650, Bethesda, MD 20815, USA

3 Present address: Inspire Environmental, 88 Silva Lane, Middletown, RI 02842, USA tagging location, although alongshore movements up to $475 \mathrm{~m}$ were recorded. Estimates of relative $F$. heteroclitus productivity, using relative density data from a concurrent study, were highest along Spartina and Phragmites, intermediate at riprap, and lowest at bulkhead. Therefore, despite greater growth rates along riprap than at vegetated shores, armoring reduces abundance sufficiently to negatively impact localized productivity of $F$. heteroclitus.

Keywords Spartina $\cdot$ Phragmites $\cdot$ Riprap $\cdot$ Bulkhead · Mark-recapture $\cdot$ Decimal coded wire tag

\section{Introduction}

Since the mid-1900s, more than $70 \%$ of the estuaries in the USA have been at least moderately degraded (Mercer 1984; Peterson et al. 2000). Degradation in many estuaries can be attributed to urbanization and shoreline development (Able et al. 1999). These processes usually occur in concert, as shoreline development is implemented to protect upland development. Shoreline armoring, including bulkhead and riprap structures, can lead to modification of hydrology (Odum 1970), increases in nutrient loads (Bilkovic and Roggero 2008), decreases in allochthonous inputs (Jennings et al. 1999; Christensen et al. 1996; Bilkovic and Roggero 2008), alteration of shallow water habitat (Jennings et al. 1999; Peterson et al. 2000; Bilkovic et al. 2006; Bilkovic and Roggero 2008), and reduction in habitat complexity (Jennings et al. 1999; Scheuerell and Schindler 2004; Bilkovic and Roggero 2008).

Alterations to the physical habitat associated with armoring shorelines can impact the associated biological communities. A study along the James River in Virginia, USA, concluded that bulkheading was associated with a significantly lower Fish Community Index (a multimetric measurement of biotic 
integrity) than either natural marsh or riprap shorelines (Bilkovic and Roggero 2008). Able et al. (1998) found that fishes were less abundant and less diverse under piers in the New York-New Jersey Harbor Estuary than in nearby natural marsh habitat or uncovered pile fields. A subsequent study showed that winter flounder (Pseudopleuronectes americanus) and tautog (Tautoga onitis) confined under piers had lower growth rates (often negative) compared to fish confined in natural marsh and uncovered pile fields (Able et al. 1999). Other studies have demonstrated impacts of shoreline modification (bulkhead, riprap, riprap-sill, rock-crib pier, retaining wall) on various biota, including the following: benthic invertebrate communities (Bilkovic et al. 2006; Seitz et al. 2006), fish eggs (Rice 2006; Balouskus and Targett 2012), predator abundances (Seitz et al. 2006), and fish community structure (Beauchamp et al. 1994; Jennings et al. 1999; Bilkovic and Roggero 2008; Balouskus and Targett 2016). However, no research has been conducted on the effects of bulkhead or riprap structures on growth and movement of the abundant estuarine resident fish species, the mummichog (Fundulus heteroclitus).

Fundulus heteroclitus spends its entire life cycle in shallow estuarine waters, and it is the most abundant fish in tidal marshes on the east coast of the USA (Kneib 1997; Able and Hagan 2000, 2003; Able et al. 2003; Hagan et al. 2007) where it reaches a maximum size of approximately $130 \mathrm{~mm}$ total length (TL) (Able and Fahay 2010). This species uses salt marsh edge and surface habitat as refuge from predation (Kneib 1987; Hagan et al. 2007), feeding areas (Weisberg and Lotrich 1982; Hagan et al. 2007), spawning sites (Able and Castagna 1975; Taylor et al. 1977; Hagan et al. 2007), and juvenile fish habitat (Kneib 1984; Talbot and Able 1984; Hagan et al. 2007). Due to its reliance on marsh habitat, $F$. heteroclitus populations are likely impacted by shoreline hardening that alters the marsh edge and can eliminate access to the marsh surface. This expectation is supported by research into the impact of marsh alteration on $F$. heteroclitus by invasive plants (Hagan et al. 2007).

Although $F$. heteroclitus utilizes native smooth cordgrass (Spartina alterniflora; hereafter Spartina) marsh, the invasive common reed (Phragmites australis; hereafter Phragmites) has been shown to negatively affect $F$. heteroclitus populations. Early juvenile $F$. heteroclitus remain in marsh pools at low tide and little or no standing water remains in Phragmites marsh after tidal flooding has left the marsh surface (Able et al. 2003; Hagan et al. 2007). Numerous studies have found the abundance of juvenile $F$. heteroclitus to be significantly lower in Phragmites marsh than in naturally occurring Spartina marsh (Able and Hagan 2000, 2003; Osgood et al. 2003; Raichel et al. 2003; Hunter et al. 2006; Osgood et al. 2006; Hagan et al. 2007). In addition, lower growth rates of $F$. heteroclitus have been reported in Phragmites compared to Spartina marshes (Hagan et al. 2007).
Any impact of shoreline hardening or Phragmites invasion on $F$. heteroclitus growth or movement could have cascading effects on local estuarine environments. Fundulus heteroclitus are a major component of estuarine nekton (Kneib 1997) and a common prey for larger estuarine species. Fundulus heteroclitus has been shown to be prey for other fishes, such as striped bass (Morone saxatilis) (Tupper and Able 2000; Nemerson and Able 2003), weakfish (Cynoscion regalis) (Nemerson 2001; Nemerson and Able 2004), white perch (Morone americana) (Nemerson and Able 2004), and Atlantic croaker (Micropogonias undulatus) (Nemerson 2001), and is therefore an important trophic link between production on the marsh surface and subtidal estuarine habitats (Kneib 1997).

Individual $F$. heteroclitus exhibit a high degree of site fidelity and small feeding range (Lotrich 1975; Able et al. 2006), so their growth rate should reflect the local environmental conditions. This allows comparisons of growth, productivity, and movement along specific vegetated and armored shorelines. Alongshore movement of $F$. heteroclitus, based on tagging studies, has been reported to be $18 \mathrm{~m}$ or less over the course of a month (Lotrich 1975) and generally $30 \mathrm{~m}$ or less (but up to $300 \mathrm{~m}$ ) over a 166-day recapture period (Able et al. 2006). This restricted home range, along with the observation of differing stable isotopes $\left(\delta^{13} \mathrm{C}\right)$ between F. heterocltius in nearby Spartina and Phragmites marshes (Currin et al. 2003), suggests that $F$. heteroclitus feeding and growth reflect localized habitat conditions. Furthermore, the opportunistic diet of F. heteroclitus (Kneib 1986) is largely determined by the available community of small benthic invertebrates (Baker-Dittus 1978), so F. heteroclitus growth and productivity can also serve as a reflection of benthic habitat quality (e.g., Goto and Wallace 2011) along localized shoreline types.

It is not known how $F$. heteroclitus growth, productivity, and movement compare among vegetated and armored shoreline types, nor is there information on movement between shoreline types. The objectives of this study were to (1) compare growth rates of $F$. heteroclitus along Spartina, Phragmites, riprap, and bulkhead shorelines, (2) estimate relative productivity of $F$. heteroclitus along these same shorelines, and (3) compare movement distance and patterns within and among shoreline types.

\section{Methods}

\section{Study Area}

This research was conducted in Pepper Creek, a tributary of Indian River Bay, in the Delaware Coastal Bays (Fig. 1). The Delaware Coastal Bays comprise a coastal lagoon estuary, with limited water exchange with the coastal ocean at Indian 
Fig. 1 (a) Delaware Coastal Bay region of the USA. (b) The Delaware Coastal Bays, comprised of Rehoboth and Indian River Bays. (c) Pepper Creek study location off Indian River Bay. Dark circles indicate study sites, labeled with site ID and shoreline lengths in meters. SP Spartina alterniflora, $P H$ Phragmites australis, $R R$ riprap, $B U$ bulkhead; numbers refer to replicates. Dark triangles show locations of multiparameter sondes

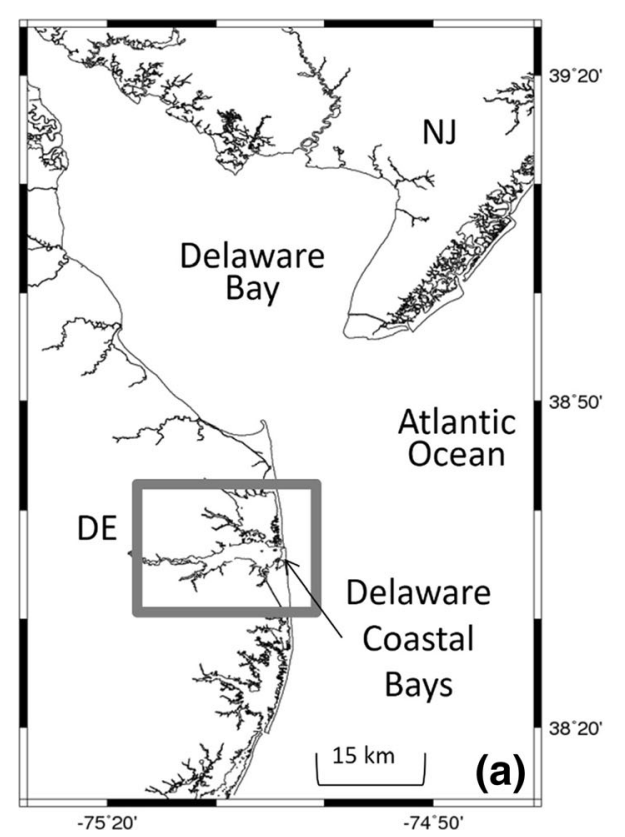

River Inlet (Tyler et al. 2009). Pepper Creek is 5-km long and varies in width from $0.75 \mathrm{~km}$ at the mouth to $0.2 \mathrm{~km}$ in the upstream portions. It has a tidal range of $0.75 \mathrm{~m}$ and a mean low water depth of $1.5 \mathrm{~m}$ in the channel and less than $0.25 \mathrm{~m}$ on the shoals. Summertime temperature and salinity typically range from 20 to $28^{\circ} \mathrm{C}$ and 15 to 25 , respectively (Tyler and Targett 2007; Tyler et al. 2009). The present study was conducted in the upper portions of the creek (Fig. 1c), where turbidity is high and sediments are primarily soft mud (Tyler and Targett 2007; Tyler et al. 2009).

Fundulus heteroclitus were sampled along four shoreline types: Spartina alterniflora marsh, Phragmites australis marsh, riprap, and bulkhead. Spartina and Phragmites sites were fringing marshes (less than 5-m wide) typical of Pepper Creek marsh shores. Two replicate sites of at least 35-m length were used at each shoreline type (Table 1; Fig. 1c). Site names used hereafter consist of shoreline type (SP for Spartina marsh, PH for Phragmites marsh, RR for riprap, or BU for bulkhead) paired with a replicate number (1 or 2). Shoreline sites were selected as close as possible to one another, within the constraints of availability, and all eight sites were within a $1.25-\mathrm{km}$ stretch of Pepper Creek. Site proximity minimized the effect of environmental differences among sites, and allowed assessment of potential movement between shoreline types, but focused applicability of the results to fringing marshes.

Water temperature and dissolved oxygen (DO) were measured every $15 \mathrm{~min}$ by 2 YSI multiparameter sondes from July 7, 2010 to September 10, 2010. Sondes were located at the upstream and downstream edges of the study area (Fig. 1c). Sondes were cleaned weekly to prevent biofouling and replaced every 3 weeks. Due to the sonde rotation schedule, and occasional sonde biofouling, data were incomplete for 5 and 10 days at the upper and lower sonde, respectively. Incomplete records were rarely on adjacent days.

\section{Tagging}

Fundulus heteroclitus were tagged with sequential decimal Coded Wire Tags (CWTs, Northwest Marine Technology, Inc.) for individual fish identification, which allowed growth rates to be determined by mark-recapture. Numerous recent mark-recapture studies have successfully used CWT with F. heteroclitus and other fishes (e.g., Teo and Able 2003; Able et al. 2006; Brennan et al. 2007; Kneib 2009). The 1.1$\mathrm{mm}$ long tags have been shown to have minimal effects on survival and behavior of $F$. heteroclitus larger than $30 \mathrm{~mm}$ TL, and retention rates are as high as $99 \%$ (Able et al. 2006). Prior to tagging, CWTs were examined under $\times 375$ magnification and each tag was stored individually with its number for quick access in the field.

Tagging occurred on 5 days between July 6 and July 20, 2011 (Table 1). Fundulus heteroclitus were collected at two locations $15 \mathrm{~m}$ apart (Fig. 2) near the center of each site using 5 unbaited cylindrical minnow traps per location. Traps were set on flooding tide for at least $1 \mathrm{~h}$, with trap opening initially just below the water surface to ensure similar depth of sampling at all sites. On shore, collected fish (40-70 mm TL) were weighed $( \pm 0.01 \mathrm{~g})$ on a digital balance, measured $( \pm 0.1 \mathrm{~mm}$ TL) with calipers, tagged, and then released back at the collection location. Tags were inserted by syringe on the left side slightly dorsal and anterior to the anal fin. Ninety F. heteroclitus (45 at each of the two locations) were tagged per site (Fig. 1c), except at PH1 where 95 fish were tagged, for 
Table 1 Shoreline types, lengths, and schedule of tagging and recapture for each replicate site. All dates are from 2011

\begin{tabular}{lllll}
\hline Site & Shoreline type & Shoreline length $(\mathrm{m})$ & Tagging dates & Recapture dates \\
\hline SP1 & Spartina & 55 & July 6, 11, 12 & Aug 13, Sept 9 \\
SP2 & Spartina & 55 & July 6, 20 & Aug 19, Sept 10 \\
PH1 & Phragmites & 55 & July 6, 11 & Aug 10, Sept 7 \\
PH2 & Phragmites & 65 & July 6, 15 & Aug 17, Sept 10 \\
RR1 & Riprap & 45 & July 6, 12 & Aug 13, Sept 9 \\
RR2 & Riprap & 55 & July 6, 20 & Aug 19, Sept 2, 20 \\
BU1 & Bulkhead & 35 & July 6, 11 & Aug 10, Sept 7 \\
BU2 & Bulkhead & 35 & July 6, 20 & Aug 17, Sept 2, 20 \\
\hline
\end{tabular}

a total of 725 tagged fish. On the first day of tagging, 1 fish was weighed 10 times to assess the precision of the weighing procedure. Maximum and minimum weight measurements differed by $3.3 \%$.

\section{Recapture}

A minimum of two rounds of recaptures were conducted at all sites between 1 and 1.5 months after tagging (Table 1). For the first round, two sites were sampled each day in the same order as tagging was done (to keep growing days similar for fish at each shoreline type). Sites RR2 and BU2 had lower numbers of recaptures during the first round, so those sites were sampled first in round two to maximize the possibility of recapturing fish; otherwise rounds one and two occurred in the same site-order. Sites RR2 and BU2 were sampled a third time because of low recapture numbers in the first two rounds (Table 1).

During recapture sampling, pairs of minnow traps were deployed at 5-m intervals, on either side of both tagging locations (Fig. 2). Trapping procedure was identical to the original collection protocol. Recaptured fish were identified using a V-detector (Northwest Marine Technology, Inc.) which detected the presence of a tag. These fish were reweighed $( \pm 0.01 \mathrm{~g})$ and remeasured $( \pm 0.1 \mathrm{~mm})$ at the same location used for initial tagging. They were then anesthetized with MS-

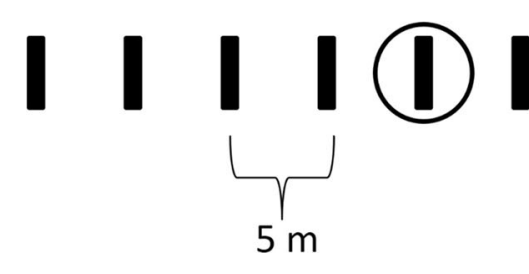

Fig. 2 Distribution of minnow traps for tagging and recapture of Fundulus heteroclitus. Fish were tagged at the 2 circled locations and recaptured at each vertical line. The illustration is for a $55-\mathrm{m}$ section of
222, frozen on dry ice, and returned to the laboratory for tag extraction, number identification, and sex determination.

Extracted tags were cleaned with ethanol and identified under $\times 375$ magnification. Sex of fish was determined based primarily on external characteristics (Murdy et al. 1997; Lopez et al. 2010). Female $F$. heteroclitus have an ovipositor along the first spine of the anal fin and are more drab in color than males. Five fish were dissected and examined internally, which confirmed sex based on external characteristics.

\section{Data Analysis}

\section{Temperature and Dissolved Oxygen}

Temperature measurements from the two multiparameter sondes were used to determine the maximum, minimum, and mean temperature at each sonde location. Mean tributary temperature was calculated for each 15-min point as the average of the two values and correlations between individual sonde temperatures and mean temperatures were used to estimate means for times when only one sonde was active. Mean tributary temperature could thus be calculated over any time period, allowing temperature experienced by fish over different periods to be considered when comparing shoreline-specific growth rate results.

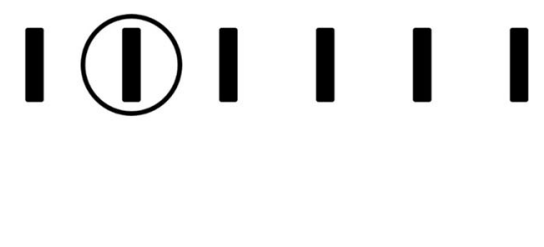

shoreline. Recapture locations were added or subtracted as necessary, for longer or shorter shorelines, by adding or eliminating outer traps 


\section{Growth Rate}

For each recaptured fish, linear growth rate $\left(\mathrm{mm} \mathrm{day}^{-1}\right)$ and specific growth rate ( $\%$ body mass day ${ }^{-1}$ ) were calculated according to Ricker (1975) as:

Linear growth rate $=\frac{L_{f}-L_{i}}{\Delta t}$

Specific growth rate $=\left(e^{G}-1\right) \cdot 100$

$G=$ Instantaneous growth rate $=\frac{\ln \left(W_{f}\right)-\ln \left(W_{i}\right)}{\Delta t}$

where $L_{f}$ is final length and $L_{i}$ is initial length, $W_{f}$ is final weight and $W_{i}$ is initial weight, and $\Delta t$ is time in days between final and initial measurements.

Fish recaptured at the same site were assumed to have not moved from that shoreline type. Our goal was to analyze these "non-mover" $F$. heteroclitus for the effects of 3 independent variables (shoreline type, replicate sites at each shoreline type, and sex) on 3 dependent variables (linear growth rate (LGR), specific growth rate (SGR), and movement distance). Site BU2 was excluded from the analyses because only one fish was recaptured there; results were similar with and without BU2. Growth data required pooling and transformation to be properly analyzed. Number of recaptures precluded analyzing the growth data by either partially nested ANOVA (replicate sites and sex nested within shoreline) or separate nested
ANOVAs (replicate sites nested within shoreline) for each sex. In such analyses, a third of the groups would have contained 3 or fewer samples and half would have contained 4 or fewer samples, so tests were run to see if data could be pooled by site or by sex. The appropriateness of pooling replicate sites was tested with nested ANOVAs (sites nested within shoreline) and pooling by sex of fish was tested with 2-way ANOVAs (shoreline + sex) with Tukey multiple comparisons (Table 2). Specific growth rate data were natural log transformed (referred to as tSGR) because of heteroscedasticity. Based on a cutoff at a critical value of 0.25 for pooling (Underwood 1997; Beninger et al. 2012), growth rate data could be pooled by replicate sites but not by sex. Initial length data did not meet the pooling criteria by replicate sites; however, because initial length was being considered as a confounding factor for the growth rate analyses, pooling by site was necessary.

With the replicate sites data pooled, growth rate was analyzed with 2-way ANOVAs, and Tukey multiple comparisons, to examine effects of shoreline and sex on LGR and tSGR (Table 2). Initial length data exhibited heteroscedasticity that could not be remedied with data transformations, so initial length data were analyzed with a 1-way ANOVA with a Welch's test (by shoreline, for which data were heteroscedasctic) and Games-Howell multiple comparisons, and with a 1-way ANOVA (by sex, for which data was not heteroscedastic) and Tukey multiple comparisons. Welch's test and Games-Howell multiple comparisons are more appropriate for analysis of heteroscedastic data than an ANOVA

Table 2 Summary statistics for growth rate and length data analyses

\begin{tabular}{|c|c|c|c|c|c|c|c|}
\hline \multirow[t]{2}{*}{ Test } & \multirow[t]{2}{*}{ Factor $(d f)$} & \multicolumn{3}{|c|}{ Type III SS } & \multicolumn{3}{|c|}{$p$ value, $F$ statistic } \\
\hline & & LGR & tSGR & $\mathrm{IL}^{\mathrm{b}}$ & LGR & tSGR & $\mathrm{IL}^{\mathrm{b}}$ \\
\hline \multirow[t]{4}{*}{ Nested ANOVA } & Shoreline (3) & 0.095 & 0.829 & 378.481 & $0.11,5.58$ & $0.04,66.63$ & $0.45,1.18$ \\
\hline & Error (1.4-2.9) & 0.016 & 0.006 & 308.239 & & & \\
\hline & Site $^{\mathrm{a}}(3)$ & 0.017 & 0.017 & 312.789 & $0.42,0.96$ & $0.94,0.13$ & $0.1,2.2$ \\
\hline & Error (73) & 0.433 & 3.121 & 3459.07 & & & \\
\hline \multirow[t]{4}{*}{ 2-way ANOVA } & Shoreline (3) & 0.095 & 0.917 & - & $0.002,5.40$ & $<0.001,7.47$ & - \\
\hline & $\operatorname{Sex}(1)$ & 0.027 & 0.052 & - & $0.03,4.66$ & $0.26,1.28$ & - \\
\hline & Interaction (3) & 0.001 & 0.108 & - & $0.99,0.03$ & $0.45,0.88$ & - \\
\hline & Error (72) & 0.420 & 2.946 & & & & \\
\hline 1-way ANOVA (Welch) & Shoreline $(3,39.412)$ & & & & & & $0.08,2.47^{\mathrm{c}}$ \\
\hline \multirow[t]{2}{*}{ 1-way ANOVA } & Among sex (1) & & & 46.043 & & & $0.34,0.91$ \\
\hline & Within sex (78) & & & 3966.19 & & & \\
\hline
\end{tabular}

$L G R$ linear growth rate, tSGR natural log transformed specific growth rate (see Methods section), and $I L$ initial length. Nested ANOVA justified pooling sites; 2-way ANOVA showed sex could not be pooled. Two 1-way ANOVAs (one with a Welch test) were used for initial length data because of heteroscedasticity (see Methods section)

${ }^{\text {a }}$ Site is nested within shoreline

${ }^{\mathrm{b}}$ IL 2-way ANOVA could not be done due to heteroscedasticity

${ }^{\mathrm{c}}$ Welch statistic 
with Tukey multiple comparisons. ANOVAs were performed in SPSS and a critical value of 0.05 was considered significant for all tests.

\section{Shoreline-Specific Relative Productivity}

Relative productivity of $F$. heteroclitus along each shoreline type was estimated by multiplying relative shoreline-specific density by relative shoreline-specific instantaneous growth rate as: $\dot{P}=\dot{D} \cdot \dot{G}$; where $\dot{P}$ is relative productivity, $\dot{D}$ is relative density, and $G$ is relative instantaneous growth rate. Shoreline-specific density of $F$. heteroclitus $\left(\# \mathrm{~m}^{-2}\right)$ data were available on 11 dates, between July 7 and September 15, 2010, from a concurrent seining study (Balouskus 2012; Balouskus and Targett 2017) in the same section of upper Pepper Creek. Density was considered a reasonable proxy for biomass because the average length of $F$. heteroclitus from each shoreline in the concurrent study was similar: 51, 51, 54, and $57 \mathrm{~mm}$ standard length (SL) at Spartina, Phragmites, riprap, and bulkhead, respectively. To establish relative productivity, growth rate, and density, values from each shoreline were normalized to the same base. Any shoreline could serve as this base and we used riprap, for which values were set at 1 .

\section{Movement Distance}

Placement of traps at 5-m intervals during recapture sampling meant that fish at longer shoreline sites (Table 1; Fig. 1c) could move farther from their tagging locations and still be recaptured at that site/shoreline type. To make the movement distance metric comparable across all sites, only the fish recaptured at the 8 recapture locations nearest their site's tagging locations were considered in the within-site movement distance analysis. Movement distances within sites were categorized into recaptures $\leq 5 \mathrm{~m}$ from the tagging site and recaptures $>5 \mathrm{~m}$ from the tagging site. Fish counts in each category were compared among shoreline types with chisquare tests of independence for male and female fish. To determine if movement behavior was related to fish size, a Welch's $t$ test was run on initial length of those fish that moved from the shoreline at which they were tagged vs all those that did not, for males and females.

\section{Results}

Overall, $89(12 \%)$ of the 725 tagged $F$. heteroclitus were recaptured; 81 of which $(91 \%)$ were recaptured at the same shoreline site at which they had been tagged (Table 3 ). Temperatures at the upstream and downstream sondes were similar; mean, maximum, and minimum temperatures were 28.8, 33.7, and $23.9^{\circ} \mathrm{C}$, respectively, at the upper sonde and
28.3, 33.9, and $23.3{ }^{\circ} \mathrm{C}$, respectively, at the lower. Average temperature experienced by fish tagged on the first tagging day and recaptured on the first recapture day $\left(29.5^{\circ} \mathrm{C} \pm 0.02\right.$ $\mathrm{SE})$ was similar to that experienced by fish tagged on the last day of tagging and recaptured on the last day $\left(28.0^{\circ} \mathrm{C} \pm 0.03\right.$ $\mathrm{SE})$. Pepper Creek undergoes diel cycles of dissolved oxygen during summer (Tyler et al. 2009), and dissolved oxygen (DO) levels were similar at the two sondes. Average daily mean, maximum, and minimum DO was 5.29, 9.98, and $1.55 \mathrm{mg} \mathrm{O}_{2} \mathrm{~L}^{-1}$, respectively, at the upper sonde and 5.60,10.66, and $2.41 \mathrm{mg} \mathrm{O}_{2}$ $\mathrm{L}^{-1}$, respectively, at the lower sonde. Minor spatial and temporal differences in temperature and DO conditions were considered negligible as potentially confounding the shoreline-specific growth rate results for $F$. heteroclitus within the study area.

\section{Growth Rate}

Fundulus heteroclitus recaptured at the same site where they had been tagged were assumed to have growth rates reflecting growth along that shoreline type. Data on 80 fish that were recaptured at their tagging site, excluding BU2, were available for analysis of specific growth rate (Table 3). After pooling growth rate data by replicate sites, 2-way ANOVA tests revealed that LGR $\left(F_{3,72}=5.404, p=0.002\right)$ and tSGR $\left(F_{3,72}=7.467, p<0.001\right)$ both differed significantly by shoreline type (Table 2). Fundulus heteroclitus along vegetated shorelines (Spartina and Phragmites) grew slower than those along riprap $\left(0.15 \mathrm{~mm}^{\mathrm{day}}{ }^{-1}\right.$ and $0.65 \%$ body mass day ${ }^{-1}$, Table 3), and fish from bulkhead grew at an intermediate rate that was not significantly different from that at other shoreline types (Tables 2 and 3, Fig. 3). Female F. heteroclitus had significantly greater linear growth rates, but not greater specific growth rates, than males along all shorelines (Fig. 3).

Initial length of recaptured $F$. heteroclitus did not differ significantly between shoreline types or between sexes (Table 2), so size did not have a confounding effect on any growth rate tests. The difference between mean initial length at the shoreline with the longest fish (bulkhead) and the shortest fish (riprap) was only $5.5 \mathrm{~mm}$; and male and female fish differed by only $1.5 \mathrm{~mm}$.

\section{Shoreline-Specific Relative Productivity}

Relative productivity of $F$. heteroclitus was highest along vegetated shorelines despite having lower growth rates (Table 4). Productivity of $F$. heteroclitus was greatest along Phragmites (114\% greater than along riprap), due to a mean growth rate only $27 \%$ of that at riprap yet a nearly eight-fold greater mean density (Table 4). Fish along Spartina shoreline had the second highest relative productivity (97\% greater than at riprap), with $F$. heteroclitus along Spartina having the lowest growth rate but occurring at the highest mean density (Table 4). 


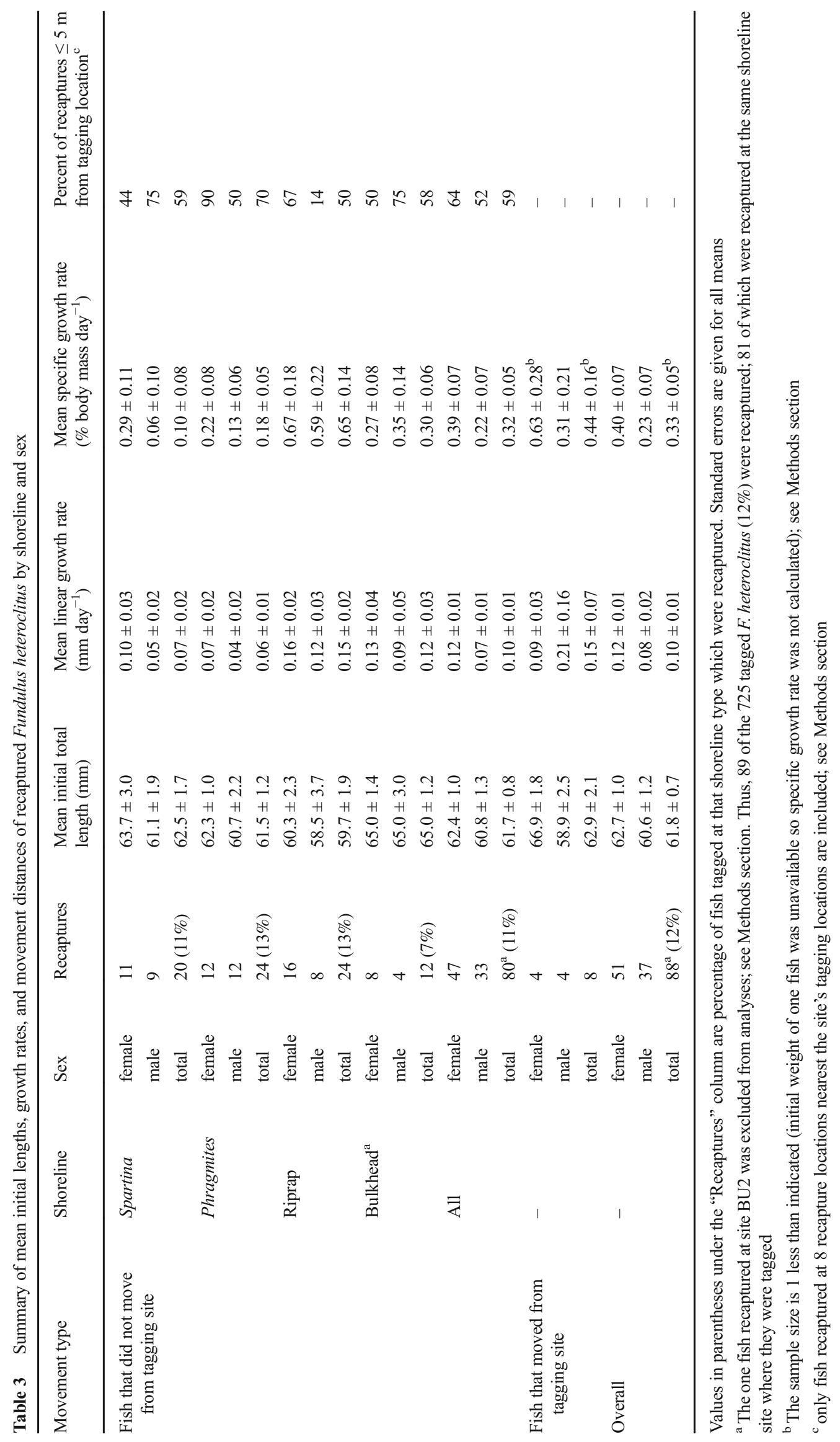


Fig. 3 (a) Linear growth rate $\left(\mathrm{mm}\right.$ day $\left.^{-1}\right)$ and (b) specific growth rate (\% body mass day $\left.{ }^{-1}\right)$ of Fundulus heteroclitus by shoreline type and sex. Growth rates with the same letter above the bar are not significantly different from one another (Tukey multiple comparisons; critical value of 0.05 ). Error bars are standard errors

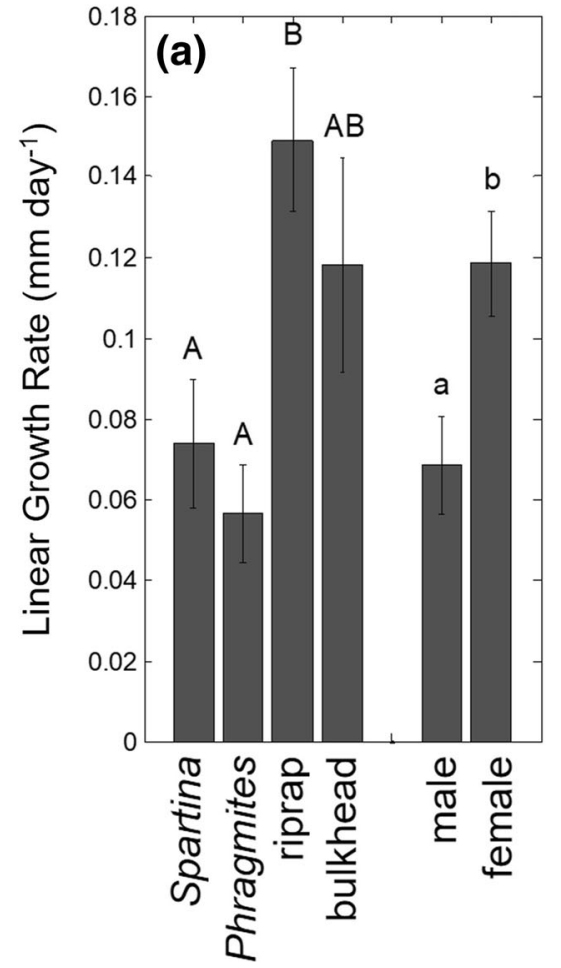

Fundulus heteroclitus along bulkhead had the lowest relative productivity, $75 \%$ less than at riprap (Table 4).

\section{Movement Distance}

Fundulus heteroclitus were recaptured 30-63 days after tagging (41 days average). Of the 89 recaptures, $22 \%$ were from their original tagging location and $47 \%$ were within $5 \mathrm{~m}$. Of the 71 fish considered for the within-site movement comparison (fish recaptured at the 8 recapture locations nearest their site's tagging locations, Fig. 2), 28\% were recaptured at their original tagging location and 59\% were recaptured within $5 \mathrm{~m}$ (Table 3). Percentage of recaptures within $5 \mathrm{~m}$ of original tagging location varied from $14 \%$ for males at riprap to $90 \%$ for females at Phragmites (Table 3; Fig. 4). Chi-square tests showed no significant difference in movement distance $(\leq 5 \mathrm{~m}$ vs $>5 \mathrm{~m})$ among shoreline types for male $\left(\chi^{2}=6.545, \chi_{d f}^{2}\right.$ $=3, p=0.09)$ or female $\left(\chi^{2}=5.171, \chi_{d f}^{2}=3, p=0.16\right)$ fish.

Of the 89 recaptured $F$. heteroclitus, 8 were recaptured at a site other than where they had been tagged (Table 3). Five fish moved 20-50 m between the contiguous RR1 and SP2 sites (Fig. 1c); 4 of which were tagged at riprap and recaptured at Spartina, and 1 was the opposite. The other 3 moved 450 $475 \mathrm{~m}$ from RR1 to PH2, BU2 to RR1, and PH2 to SP2 (Fig. 1c). Only 1 of the 8 fish moved from a vegetated site (SP2) to an armored site (RR1). The female $F$. heteroclitus that moved from their tagging site were significantly larger $(t=2.605$, $\left.t_{d f}=6.52, p=0.04\right)$ than those that had not, whereas the males

Table 4 Shoreline-specific relative productivity of Fundulus heteroclitus calculated using instantaneous growth rates from the present study multiplied by aerial densities (biomass proxy) from a concurrent seining study in the same section of upper Pepper Creek (Balouskus 2012); see Balouskus and Targett (2017) for methods

\begin{tabular}{llcc}
\hline Shoreline & $\begin{array}{l}\text { Relative instantaneous } \\
\text { growth rate }\end{array}$ & $\begin{array}{c}\text { Relative biomass } \\
\text { (density) }\end{array}$ & Relative productivity \\
\hline Spartina & 0.16 & $12.35(37.67)$ & 1.97 \\
Phragmites & 0.27 & $7.94(24.23)$ & 2.14 \\
Riprap & 1 & $1(3.05)$ & 1 \\
Bulkhead & 0.46 & $0.54(1.64)$ & 0.25
\end{tabular}

Growth rates and densities were normalized to those at riprap (where values were set at 1 ) to generate relative values (see Methods section). Unnormalized density values (fish $\mathrm{m}^{-3}$ ) from which the relative biomass values were determined are included in parentheses for context 


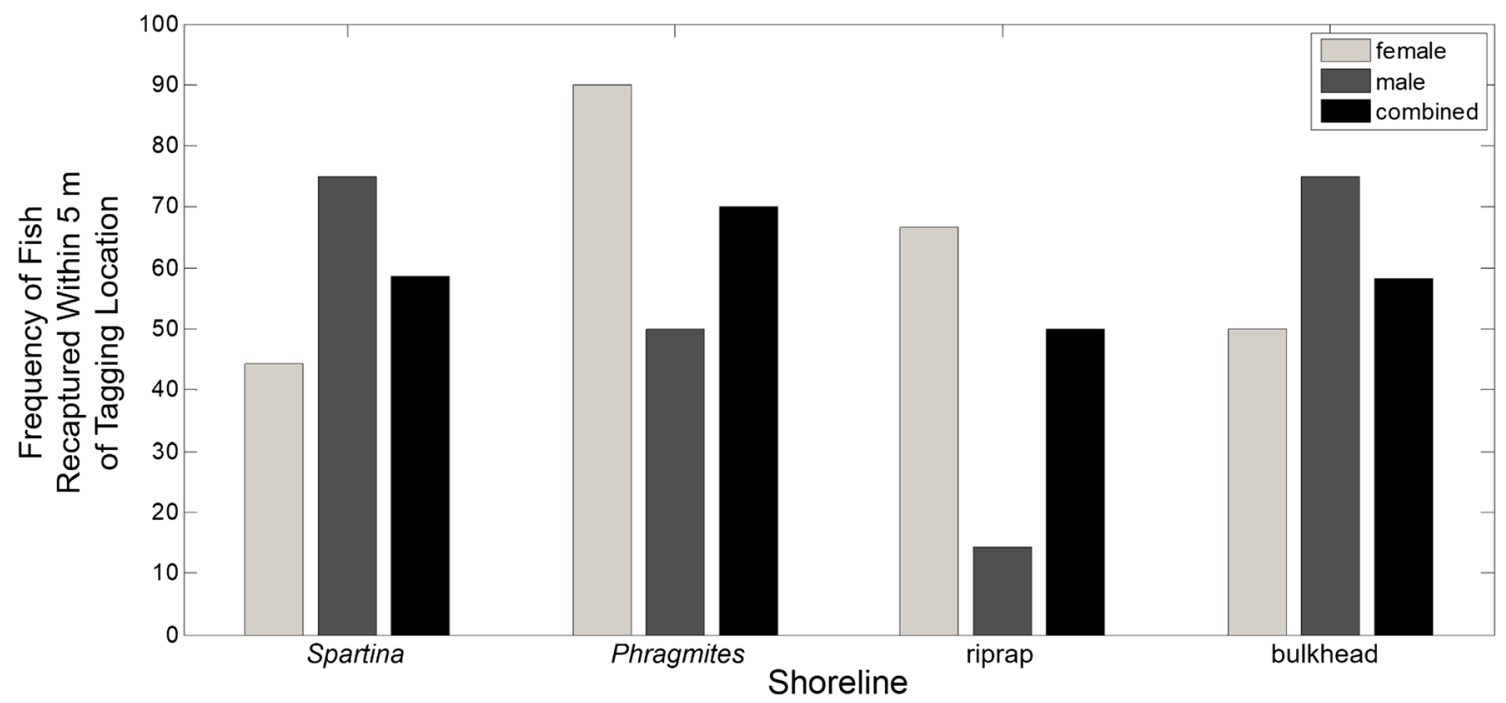

Fig. 4 Frequency of recaptured Fundulus heteroclitus that were recaptured $\leq 5 \mathrm{~m}$ from their tagging location, by shoreline type and sex. These numbers refer to the 71 fish considered in the movement distance analysis

in the two groups did not differ significantly in size $\left(t=-0.776, t_{d f}=5.35, p=0.47\right)$.

\section{Discussion}

\section{Growth Rate}

There have been no previous studies of $F$. heteroclitus growth along armored shorelines, or comparisons of growth along armored structures with growth at vegetated shores. Growth rate along riprap $\left(0.15 \mathrm{~mm} \mathrm{day}^{-1}\right)$ was significantly higher than along Spartina $\left(0.07 \mathrm{~mm}\right.$ day $\left.^{-1}\right)$ and Phragmites $\left(0.06 \mathrm{~mm} \mathrm{day}^{-1}\right)$ shorelines, whereas growth along bulkhead $\left(0.12 \mathrm{~mm} \mathrm{day}^{-1}\right)$ was intermediate and not significantly different from the other shorelines. Mean growth rate at Spartina sites in this study is lower than rates reported in previous studies in Delaware Spartina marsh habitat. Growth rates of $0.20-0.25 \mathrm{~mm} \mathrm{day}^{-1}$ were reported for similar sized F. heteroclitus in Spartina marsh during summertime (Teo and Able 2003; Hagan et al. 2007). Hagan et al. (2007) also reported significantly lower summertime growth for F. heteroclitus in Phragmites than in Spartina marsh $(0.13$ and $0.24 \mathrm{~mm} \mathrm{day}^{-1}$, respectively), with the difference less pronounced during August-September.

Shoreline hardening is generally done to protect adjacent upland development, so shoreline hardening is most likely to occur at fringing marsh (Currin et al. 2008). Most of the marsh shorelines along Pepper Creek are fringing marshes, and the Spartina and Phragmites sites in this study were 2-5-m wide. Narrow marsh width can limit the amount of flooded marsh surface available to $F$. heteroclitus, which typically move onto the marsh surface at high tide to feed (Weisberg et al. 1981;
Weisberg and Lotrich 1982; Javonillo et al. 1997). This may be why observed growth rates at Spartina and Phragmites sites in this study are lower than those reported in previous studies on $F$. heteroclitus from the interior of more extensive marsh systems (Teo and Able 2003; Hagan et al. 2007), and it may also contribute to the similarity in growth rate at the two vegetated sites in the present study. Comparisons of the ecological benefits of fringing marsh versus more extensive interior marsh for feeding and growth of fishes are warranted.

The higher growth rate along riprap shorelines than at Spartina and Phragmites can potentially be attributed to density-dependent processes associated with absolute and per-fish prey availability. The available literature suggests that $F$. heteroclitus inhabit vegetated shorelines at sufficient densities to be food limited, since they exhibit density-dependent growth both on the marsh surface and in the adjacent subtidal zone (Kneib 1981; Weisberg and Lotrich 1982, 1986; Lockfield et al. 2013). Fundulus heteroclitus typically feed on benthic invertebrates, such as small crustaceans and polychaetes, and may consume large amounts of plant material when prey is scarce, although detritus is likely of little nutritional value (Prinslow et al. 1974; Baker-Dittus 1978; Kneib and Stiven 1978; Kneib 1986). Weisberg and Lotrich (1982) showed that $F$. heteroclitus caged without access to the marsh surface grew significantly slower than those caged with marsh surface access. Furthermore, the same study showed that $F$. heteroclitus without marsh surface access grew faster than those starved under laboratory conditions, demonstrating utilization of subtidal food resources. In fact, Weisberg and Lotrich (1982) estimated that as much as $75 \%$ of the energy requirements of the $F$. heteroclitus population in Canary Creek, DE could come from subtidal sources. These results suggest density-dependent growth processes along riprap, where $F$. heteroclitus density was $<10 \%$ 
of that at Spartina. If riprap does not greatly reduce prey availability in the subtidal environment compared with Spartina, then riprap shoreline could have more food available per fish than Spartina shoreline, particularly if suitable prey are also associated with the riprap structure itself.

Seitz et al. (2006) found no significant differences in density or diversity of infauna between riprap and natural marsh shorelines in a relatively undeveloped system in Chesapeake Bay, which led to speculation that nearby marsh could "subsidize" developed shorelines in systems where proximate marsh was sufficiently abundant. In the present study, the riprap shorelines were short (45-55 m) and in close proximity to Spartina marsh. Different growth rates observed in a species with a high degree of site fidelity, such as F. heteroclitus, along different shoreline types in the present study suggest that limited stretches of shoreline (35-65-m long) have distinct microenvironments.

Female $F$. heteroclitus in the present study had significantly faster linear growth rates than males, but not faster specific growth rates. Sex-specific growth rate differences have been reported in other studies (e.g., Kneib 2009) and are consistent with the observation that females are longer than males of the same age, but males are heavier than females of the same length (Kneib and Stiven 1978).

\section{Shoreline-Specific Relative Productivity}

The estimates of shoreline-specific relative productivity were based on growth data from this study and density data from a concurrent study at the same location in upper Pepper Creek (Balouskus 2012; Balouskus and Targett 2017). Estimates showed that both Spartina and Phragmites shores supported approximately $95-115 \%$ higher relative productivity of $F$. heteroclitus than riprap, and that productivity was lowest along bulkhead. Higher growth rates of $F$. heteroclitus along armored shoreline types, particularly at riprap, was not enough to compensate for the lower densities that occur at these habitat types.

Geomorphology of the armored shorelines may have contributed to the lower F. heteroclitus densities there. Banks at the armored shorelines were steeper and reached deeper depths nearer to shore than at vegetated sites. McIvor and Odum (1988) showed that fishes, including $F$. heteroclitus, select shallow depositional habitats where invertebrate prey abundance is greater and predator pressure is less than along steeper sloped erosional banks. We speculate that armored shorelines in the present study function more like erosional tributary banks than depositional habitats, in terms of prey abundance and predation risk. Predation pressure would be further lessened at vegetated shorelines by greater access to the intertidal marsh where $F$. heteroclitus predators are less abundant (Banikas and Thompson 2012).

Potential changes in predation pressure and access to intertidal habitat due to armoring suggest that hybrid approaches may be better shoreline stabilization options. One such option is riprap-sill, which consists of a rock sill with native vegetation planted between the sill and the shore. Riprap-sills have recently been shown to offer equivalent or superior protection from erosion and higher nekton abundance compared with traditional riprap and bulkhead (Gittman et al. 2014, 2016; Balouskus and Targett 2016). Further study of the physical and biological performance of such hybrid structures is warranted.

It should be noted that the relative productivity comparisons in this study apply to $F$. heteroclitus that inhabit the shoreline edge environment, along the adjacent channel. Marsh surface habitats were not sampled. Larvae and early juveniles (up to $10 \mathrm{~mm} \mathrm{SL}$ ) stay within shallow marsh pools that remain on Spartina marsh surface, and even to a lesser extent Phragmites, after the flood tide recedes (Kneib 1984; Able and Hagan 2003). Thus, Spartina marsh likely had greater larval and early juvenile $F$. heteroclitus abundances than the other three shorelines.

\section{Movement Distance}

Twenty-two percent of the $F$. heteroclitus recaptured in the present study were at their original tagging location and $47 \%$ were within $5 \mathrm{~m}$, after 1-2 months. No significant differences in within-site movement distance were detected in male or female $F$. heteroclitus among shoreline types. These results are consistent with the high degree of site fidelity known to be a characteristic of this species, as shown by Lotrich (1975) who found that most F. heteroclitus were recaptured within $18 \mathrm{~m}$ of their tagging location in Canary Creek, Delaware. However, some individuals in the present study traveled 450-475 m between sites over 1-2 months. Other recent studies have also reported that $F$. heteroclitus can move such distances. Able et al. (2006) reported that some $F$. heteroclitus were recaptured as far as 299 m away up to 166 days after tagging in marshes along the Mullica River, a tributary of Great Bay in southern New Jersey, and Able et al. (2012) documented movements of 1000-1200 m over a 17month study in marshes and a boat basin in Great Bay. Skinner et al. (2005) reported several instances of $F$. heteroclitus movement greater than $2000 \mathrm{~m}$, and two movements of 3500-3600 $\mathrm{m}$ in just a few weeks during late spring and early summer along the shore of the upper Miramichi River estuary in northeastern New Brunswick, Canada. Meyer and Posey (2014) postulated a spring/summer spawning and recruitment phase and a late fall/winter dispersal-colonization phase for $F$. heteroclitus. We note that the 450-475 m maximum movement distances observed in the present study occurred during spring and summer when small-scale populations are postulated to be maintained, not during the largerscale dispersal phase. 
Movement of $F$. heteroclitus between shoreline types in this study was based on only 8 individuals, but 5 moved from armored to vegetated shorelines and 1 moved from vegetated to armored. The other 2 moved either between vegetated or armored shorelines. Additionally, more movement was observed between adjacent armored and Spartina shorelines than between adjacent vegetated shorelines. At the contiguous SP2 and RR1 sites, 34 tagged fish were recaptured and 5 of those fish switched between these sites (4 from riprap to Spartina and 1 in the opposite direction). However, at the contiguous vegetated sites SP1 and PH1, none of the 22 recaptured fish had moved between sites. Although sample size is limited, these results suggest that $F$. heteroclitus, at the size studied here, have a greater tendency to move from armored to vegetated shorelines, particularly to Spartina, than between Spartina and Phragmites fringing marshes.

\section{Conclusions}

This research shows that armoring shorelines along fringing marshes, where pressure to protect upland development is most likely, may negatively impact the localized productivity of $F$. heteroclitus. Although prey resources are sufficient to support greater growth rates along riprap than at Spartina and Phragmites shores, armoring reduces $F$. heteroclitus abundance sufficiently to result in reduced production. We conclude that along armored shorelines, reduced $F$. heteroclitus abundance appears to be driven by habitat characteristics other than prey limitation. The same impacts are possible for other fishes which feed opportunistically on benthic invertebrates such as small crustaceans and annelids. We also note that living shorelines, such as riprap-sills, provide shoreline protection and may mitigate the negative effects of traditional bulkheading and riprap observed in this study (Gittman et al. 2014, 2016; Balouskus and Targett 2016). The results presented here demonstrate details of the negative biological impacts associated with traditional armored shoreline structures and provide support for the importance of alternative shoreline stabilization approaches.

Acknowledgments We thank Jim and Joyce Smirk and Don and Carol Lawson for use of their property on Pepper Creek during fieldwork. Lori Davias and Dr. Ron Kneib provided insights regarding mummichog sex identification. John McDonald and Patrick Gaffney provided advice on statistical analyses, and Douglas Miller helped with MATLAB. Brittany Schieler, Ed Hale, Katherine Bogue, Adriana Arujo, and Will Hale helped with the fieldwork. We thank Northwest Marine Technology, Inc., Shaw Island, WA, for providing the sequential decimal Coded Wire Tags to test in this project.

Funding This research was supported by a grant from NOAA, National Centers for Coastal Ocean Science, Center for Sponsored Coastal Ocean Research (award number NA09NOS4780219) to T.E. Targett. Funding to K.P. Crum for supplies was provided by the University of Delaware College of Earth, Ocean, and Environment and the Undergraduate
Research Program. This is publication \#17-011 of the NOAA/CSCOR Mid-Atlantic Shorelines project.

Open Access This article is distributed under the terms of the Creative Commons Attribution 4.0 International License (http://creativecommons. org/licences/by/4.0/), which permits use, duplication, adaptation, distribution and reproduction in any medium or format, as long as you give appropriate credit to the original author(s) and the source, provide a link to Creative Commons license and indicate if changes were made.

\section{References}

Able, K.W., and M. Castagna. 1975. Aspects of an undescribed reproductive behavior in Fundulus heteroclitus (Pisces: Cyprinodontae) from Virginia. Chesapeake Science 16: 282-284.

Able, K.W., and S.M. Hagan. 2000. Effects of common reed (Phragmites australis) invasion on marsh surface macrofauna: response of fishes and decapod crustaceans. Estuaries 23: 633-646.

Able, K.W., and S.M. Hagan. 2003. Impact of common reed, Phragmites australis, on essential fish habitat: influence on reproduction, embryological development, and larval abundance of mummichog (Fundulus heteroclitus). Estuaries 26: 40-50.

Able, K.W., and M.P. Fahay. 2010. Ecology of estuarine fishes: Temperate water of the Western North Atlantic. Baltimore: The John Hopkins University Press.

Able, K.W., J.P. Manderson, and A.L. Studholme. 1998. The distribution of shallow water juvenile fishes in an urban estuary: the effects of manmade structures in the lower Hudson River. Estuaries 21: 731744.

Able, K.W., J.P. Manderson, and A.L. Studholme. 1999. Habitat quality for shallow water fishes in an urban estuary: the effects of man-made structures on growth. Marine Ecology Progress Series 187: 227 235.

Able, K.W., S.M. Hagan, and S.A. Brown. 2003. Mechanisms of marsh habitat alteration due to Phragmites: response of young-of-the-year mummichog (Fundulus heteroclitus) to treatment for Phragmites removal. Estuaries 26: 484-494.

Able, K.W., S.M. Hagan, and S.A. Brown. 2006. Habitat use, movement, and growth of young-of-the-year Fundulus spp. in southern New Jersey salt marshes: comparisons based on tag/recapture. Journal of Experimental Marine Biology and Ecology 335: 177-187.

Able, K.W., D.N. Vivian, G. Petruzzelli, and S.M. Hagan. 2012. Connectivity among salt marsh subhabitats: residency and movements of the mummichog (Fundulus heteroclitus). Estuaries and Coasts 35: 743-753.

Baker-Dittus, A.M. 1978. Foraging patterns of three sympatric killifish. Copeia 1978: 383-389.

Balouskus, R.G. 2012. Effects of altered shorelines on macrofauna and diel-cycling hypoxia in tidal tributaries of Delaware Bay and Delaware Coastal Bays. M.S. Thesis. University of Delaware, Newark, DE. 193p.

Balouskus, R.G., and T.E. Targett. 2012. Egg deposition by Atlantic silverside, Menidia menidia: substrate utilization and comparison of natural and altered shoreline type. Estuaries and Coasts 35: $1100-1109$.

Balouskus, R.G., and T.E. Targett. 2016. Fish and blue crab density along a riprap-sill-hardened shoreline: comparisons with Spartina marsh and riprap. Transactions of the American Fisheries Society 145: 766-773.

Balouskus, R.G., and T.E. Targett. 2017. Impact of armored shorelines on shore-zone fish density in a Mid-Atlantic, USA, estuary: modulation 
by hypoxia and temperature. Estuaries and Coasts. https://doi.org/ 10.1007/s12237-017-0258-6.

Banikas, E.M., and J.S. Thompson. 2012. Predation risk experienced by mummichog, Fundulus heteroclitus, in intertidal and subtidal salt marsh habitats. Estuaries and Coasts 35: 1346-1352.

Beauchamp, D.A., E.R. Byron, and W.A. Wurtsbaugh. 1994. Summer habitat use by littoral-zone fishes in Lake Tahoe and the effects of shoreline structures. North American Journal of Fisheries Management 14: 385-394.

Beninger, P.G., I. Boldina, and S. Katsanevakis. 2012. Strengthening statistical usage in marine ecology. Journal of Experimental Marine Biology and Ecology 426-427: 97-108.

Bilkovic, D.M., and M.M. Roggero. 2008. Effects of coastal development on nearshore estuarine nekton communities. Marine Ecology Progress Series 358: 27-39.

Bilkovic, D.M., M.M. Roggero, C.H. Hershner, and K.H. Havens. 2006. Influence of land use on macrobenthic communities in nearshore estuarine habitats. Estuaries and Coasts 29: 1185-1195.

Brennan, N.P., K.M. Leber, and B.R. Blackburn. 2007. Use of coded-wire and visible implant elastomer tags for marine stock enhancement with juvenile red snapper Lutjanus campechanus. Fisheries Research 83: 90-97.

Christensen, D.L., B.R. Herwig, D.E. Schindler, and S.R. Carpenter. 1996. Impacts of lakeshore residential development on coarse woody debris in north temperate lakes. Ecological Applications 6: $1143-1149$

Currin, C.A., S.C. Wainright, K.W. Able, M.P. Weinstein, and C.M. Fuller. 2003. Determination of food web support and trophic position of the mummichog, Fundulus heteroclitus, in New Jersey smooth cordgrass (Spartina alterniflora), common reed (Phragmites australis), and restored salt marshes. Estuaries 26: 495-510.

Currin, C.A., P.C. Delano, and L.M. Valdes-Weaver. 2008. Utilization of a citizen monitoring protocol to assess the structure and function of natural and stabilized fringing salt marshes in North Carolina. Wetlands Ecology and Management 16: 97-118.

Gittman, R.K., A.M. Popowich, J.F. Bruno, and C.H. Peterson. 2014. Marshes with and without sills protect estuarine shorelines from erosion better than bulkheads during a Category 1 hurricane. Ocean and Coastal Management 102: 94-102.

Gittman, R.K., C.H. Peterson, C.A. Currin, F.J. Fodrie, M.F. Piehler, and J.F. Bruno. 2016. Living shorelines can enhance the nursery role of threatened estuarine habitats. Ecological Applications 26: 249-263.

Goto, D., and W.G. Wallace. 2011. Altered feeding habits and strategies of a benthic forage fish (Fundulus heteroclitus) in chronically polluted tidal salt marshes. Marine Environmental Research 72: 75-88.

Hagan, S.M., S.A. Brown, and K.W. Able. 2007. Production of mummichog (Fundulus heteroclitus): response in marshes treated for common reed (Phragmites australis) removal. Wetlands 27: 54-67.

Hunter, K.L., D.A. Fox, L.M. Brown, and K.W. Able. 2006. Responses of resident marsh fishes to stages of Phragmites australis invasion in three mid Atlantic estuaries. Estuaries and Coasts 29: 487-498.

Javonillo, R., L. Deegan, K. Chiravalle, and J. Hughes. 1997. The importance of access to salt-marsh surface to short-term growth of Fundulus heteroclitus in a New England salt marsh. The Biological Bulletin 193: 288-289.

Jennings, M.J., M.A. Bozek, G.R. Hatzenbeler, E.E. Emmons, and M.D. Staggs. 1999. Cumulative effects of incremental shoreline habitat modification on fish assemblages in north temperate lakes. North American Journal of Fisheries Management 19: 18-27.

Kneib, R.T. 1981. Size-specific effects of density on the growth, fecundity and mortality of the fish Fundulus heteroclitus in an intertidal salt marsh. Marine Ecology Progress Series 6: 203-212.

Kneib, R.T. 1984. Patterns in the utilization of the intertidal salt marsh by larvae and juveniles of Fundulus heteroclitus (Linnaeus) and
Fundulus luciae (Baird). Journal of Experimental Marine Biology and Ecology 83: 41-51.

Kneib, R.T. 1986. The role of Fundulus heteroclitus in salt marsh trophic dynamics. American Zoologist 26: 259-269.

Kneib, R.T. 1987. Predation risk and use of intertidal habitats by young fishes and shrimp. Ecology 68: 379-86.

Kneib, R.T. 1997. The role of tidal marshes in the ecology of estuarine nekton. Oceanography and Marine Biology: An Annual Review 35: $163-220$

Kneib, R.T. 2009. Genotypic variation does not explain differences in growth of mummichogs Fundulus heteroclitus from simple and complex tidal marsh landscapes. Marine Ecology Progress Series 386: 207-219.

Kneib, R.T., and A.E. Stiven. 1978. Growth, reproduction, and feeding of Fundulus heteroclitus (L.) on a North Carolina salt marsh. Journal of Experimental Marine Biology and Ecology 31: 121-140.

Lockfield, K.C., J.W. Fleeger, and L.A. Deegan. 2013. Mummichog Fundulus heteroclitus responses to long-term, whole-ecosystem nutrient enrichment. Marine Ecology Progress Series 492: 211-222.

Lopez, J.D., M.S. Peterson, E.T. Lang, and A.M. Charbonnet. 2010. Linking habitat and life history for conservation of the rare saltmarsh topminnow Fundulus jenkinsi: morphometrics, reproduction, and trophic ecology. Endangered Species Research 12: 141-155.

Lotrich, V.A. 1975. Summer home range and movements of Fundulus heteroclitus (Pisces: Cyprinodontidae) in a tidal creek. Ecology 56: 191-198.

McIvor, C.C., and W.E. Odum. 1988. Food, predation risk, and microhabitat selection in a marsh fish assemblage. Ecology 69: 13411351.

Mercer, L.P. 1984. A biological and fisheries profile of spotted seatrout, Cynoscion nebulosus. North Carolina Dept. Nat. Res. And Comm. Develop., N.C. Special Scientific Report 40, Morehead City.

Meyer, D.L., and M.H. Posey. 2014. Isolated salt marsh colonization by a resident species, mummichog (Fundulus heteroclitus), and a transient species, pinfish (Lagodon rhomboides). Journal of Experimental Marine Biology and Ecology 460: 197-210.

Murdy, E.O., R.S. Birdsong, and J.A. Musick. 1997. Fishes of Chesapeake Bay. Washington, DC: Smithsonian Institution Press.

Nemerson, D.M. 2001. Trophic dynamics and habitat ecology of the dominant fish of Delaware Bay (USA) marsh creeks. Ph.D. Dissertation, Rutgers University, New Brunswick. 232p.

Nemerson, D.M., and K.W. Able. 2003. Spatial and temporal patterns in the distribution and feeding habits of Morone saxatilis in marsh creeks of Delaware Bay, USA. Fisheries Management and Ecology 10: 337-348.

Nemerson, D.M., and K.W. Able. 2004. Spatial patterns in diet and distribution ofj uveniles of four fish species in Delaware Bay marsh creeks: factors influencing fish abundance. Marine Ecology Progress Series 276: 249-262.

Odum, W.E. 1970. Insidious alteration of the estuarine environment. Transactions of the American Fisheries Society 4: 836-847.

Osgood, D.T., D.J. Yozzo, R.M. Chambers, D. Jacobson, T. Hoffman, and J. Wnek. 2003. Tidal hydrology and habitat utilization by resident nekton in Phragmites and non-Phragmites marshes. Estuaries 26: 522-533.

Osgood, D.T., D.J. Yozzo, R.M. Chambers, S. Pianka, J. Lewis, and C. LePage. 2006. Patterns of habitat utilization by resident nekton in Phragmites and Typha marshes of the Hudson River Estuary, New York. American Fisheries Society Special Symposium 51: 151-73.

Peterson, M.S., B.H. Comyns, J.R. Hendon, P.J. Bond, and G.A. Duff. 2000. Habitat use by early life-history stages of fishes and crustaceans along a changing estuarine landscape: differences between natural and altered shoreline sites. Wetlands Ecology and Management 8: 209-219. 
Prinslow, T.E., I. Valiela, and J.M. Teal. 1974. The effect of detritus and ration size on the growth of Fundulus heteroclitus (L.). Journal of Experimental Marine Biology and Ecology 16: 1-10.

Raichel, D.L., K.W. Able, and J.M. Hartman. 2003. The influence of Phragmites (common reed) on the distribution, abundance, and potential prey of a resident marsh fish in the Hackensack Meadowlands, New Jersey. Estuaries 26: 511-521.

Rice, C.A. 2006. Effects of shoreline modification on a northern Puget Sound beach: microclimate and embryo mortality in surf smelt (Hypomesus pretiosus). Estuaries and Coasts 29: 63-71.

Ricker, W.E. 1975. Computation and interpretation of biological statistics of fish populations. Ottawa: Department of the Environment, Fisheries and Marine Service.

Scheuerell, M.D., and D.E. Schindler. 2004. Changes in the spatial distribution of fishes in lakes along a residential development gradient. Ecosystems 7: 98-106.

Seitz, R.D., R.N. Lipcius, N.H. Olmstead, M.S. Seebo, and D.M. Lambert. 2006. Influence of shallow-water habitats and shoreline development on abundance, biomass, and diversity of benthic prey and predators in Chesapeake Bay. Marine Ecology Progress Series 326: 11-27.

Skinner, M.A., S.C. Courtenay, W.R. Parker, and R.A. Curry. 2005. Site fidelity of mummichogs (Fundulus heteroclitus) in an Atlantic Canadian Estuary. Water Quality Research Journal of Canada 40: 288-298.

Talbot, C.W., and K.W. Able. 1984. Composition and distribution of larval fishes in New Jersey high marshes. Estuaries 7: 434-443.
Taylor, M.H., L. Di Michele, and G.J. Leach. 1977. Egg stranding in the life cycle of the mummichog, Fundulus heteroclitus. Copeia 1977: 397-399.

Teo, S.L.H., and K.W. Able. 2003. Growth and production of the mummichog (Fundulus heteroclitus) in a restored salt marsh. Estuaries 26: $51-63$.

Tupper, M., and K.W. Able. 2000. Movements and food habits of striped bass (Morone saxatilis) in Delaware Bay (USA) salt marshes: comparison of a restored and a reference marsh. Marine Biology 137: $1049-1058$.

Tyler, R.M., and T.E. Targett. 2007. Juvenile weakfish Cynoscion regalis distribution in relation to diel-cycling dissolved oxygen in an estuarine tributary. Marine Ecology Progress Series 333: 257-269.

Tyler, R.M., D.C. Brady, and T.E. Targett. 2009. Temporal and spatial dynamics of diel-cycling hypoxia in estuarine tributaries. Estuaries and Coasts 32: 123-145.

Underwood, A.J. 1997. Experiments in ecology: Their logical design and interpretation using analysis of variance. Cambridge: Cambridge University Press.

Weisberg, S.B., and V.A. Lotrich. 1982. The importance of an infrequently flooded intertidal marsh surface as an energy source for the mummichog Fundulus heteroclitus: an experimental approach. Marine Biology 66: 307-310.

Weisberg, S.B., and V.A. Lotrich. 1986. Food limitation of a Delaware salt marsh population of the mummichog, Fundulus heteroclitus (L.). Oecologia 68: 168-173.

Weisberg, S.B., R. Whalen, and V.A. Lotrich. 1981. Tidal and diurnal influence on food consumption of a salt marsh killifish Fundulus heteroclitus. Marine Biology 61: 243-246. 